\title{
СУЧАСНЕ РОЗУМІННЯ ТОВАРУ ЯК ПРЕДМЕТУ ТОРГІВЛІ
}

\author{
Данило Світлана Іванівна \\ кандидат економічних наук, \\ Ужгородський торговельно-економічний інститут КНТЕУ (м. Ужгород, Україна) \\ ORCID0000-0003-3300-7172 \\ kveta_utei@ukr.net
}

У статті проаналізовані підходи щодо сучасного трактування «товару», як економічної категорії, що дозволяє вийти на новий рівень наукового дослідження сутності та перспектив розвитку торгівлі. Визначені напрями, за якими доцільно здійснювати оцінювання ефективності еластичності попиту на ті чи інші товари. Проаналізовано структуру соціального попиту взаємних впливів у споживчому попиті покупиів.

Ключові слова: товар, торгівля, споживчі товари, попит, споживачі.

DOI: https://doi.org/10.32845/bsnau.2019.2.2

Постановка проблеми. Торгівля $€$ найважливішою сфрерою формування і стабілізації споживчого ринку, координуючою ланкою в системі міжгалузевих, регіональних та міжрегіональних зв'язків, дієвим механізмом задоволення соціальних потреб. Вона є однією з могутніших галузей економіки будь-якої держави як за обсягом діяльності, так і за чисельністю зайнятого в ній персоналу, а підприємства цієї галузі $€$ найбільш масовими.

У сфері торгівлі споживачі купують чи придбають іншим способом товар для особистого споживання. Предметом торгівлі $€$ товари, споживні властивості яких впливають на процес товарно-грошового обміну.

Метою статті є визначення сутності товару та обґрунтування його розуміння як предмету торгівлі.

Виклад основного матеріалу. На сьогодні основним об'єктом усіх торговельних процесів є товар, який формує на ринку як попит, так і пропозицію. Для споживачів кожний товар задовольняє різні потреби і має різне значення, то варто визначити основні його поняття та суть, тобто товар це:

- матеріальна продукція, призначена для купівлі продажу. До інших об'єктів нематеріальної продукції можна віднести послуги, цінні папери, гроші, продукцію інтелектуальної праці [1];

- все що може задовольнити потреби людини і пропонується на ринку з метою привернення уваги, придбання, використання або споживання [2];

- складне поняття і не менш складний матеріальний об'єкт, який має деякі споживні властивості. Тому він і складає об'єкт особливої науки - товарознавства.

Товарознавство - наука про основоположні характеристики товарів, які визначають їх споживні властивості, і чинники забезпечення цих характеристик [1].

Для сучасного розуміння товару характерний особливий методологічний підхід: товар - це система внутрішніх зв'язків, що забезпечує впорядкованість певного набору елементів, їхню відносну стійкість.

$€$ три рівні життєвого циклу товару: товар у задумі, товар у реальному виконанні (корисні для людини властивості, споживна цінність), товар з підкріпленням (сервісне обслуговування покупця, який вибрав товар) [2].

Корисність товару - це його здатність задовольняти потреби покупця. Корисність товару, в тому числі й граничну корисність, не можна розглядати як лише психологічне поняття, що передбачає використання психологічних критеріїв,

які можуть не відповідати природі економічного аналізу. Хоча, безумовно, серйозного конфлікту між економічним і психологічним аналізом корисності споживчого товару не існує. Кількість корисності відповідає кількості отриманого від товару задоволення. Корисність можна відобразити як спадну функцію від кількості спожитого товару. Теорія обміну у цьому плані $€$ наслідком дії закону корисності; баланс корисностей двох різних товарів призводить до їх еквівалентного обміну.

Для розуміння сутності корисності товару важливим $€$ той факт, що покупці придбавають не стільки самі по собі товари, скільки їх корисні характеристики. Споживач задовольняє потреби не за допомогою товарів як таких, а за допомогою їх корисних характеристик. Товари, як правило, мають множину характеристик, які повинні бути виміряні. При цьому покупцю необхідно зробити вибір між двома наборами характеристик споживчих товарів. Ця процедура вимагає не тільки часу у межах даної ситуації вибору товару у сфері торгівлі, а й досвіду. Певні товари можуть бути використані покупцями в певній комбінації для того, щоб отримати від них потрібний набір споживчих характеристик.

У сучасних умовах значну частку корисності товару складають його нематеріальні інформаційні та сервісні атрибути (наприклад, імідж бренда), які стимулюються рекламою. Реклама є дієвим інструментом у модифікації споживчої поведінки покупця, приверненні його уваги до певного товару. Сучасним підприємствам торгівлі необхідна комплексна, ретельно розроблена і чітко спланована рекламна компанія.

Реклама має застосовуватися як засіб добросовісної інформації покупців (споживачів) про якість і призначення тих чи інших товарів.

Інформація про товари необхідна, щоб забезпечити покупцю усвідомлений і компетентний вибір продукту, інформація при цьому повинна бути, як мінімум, доступною, достовірною і своєчасною.

Економічна категорія «товар» вже давно увійшла в наукову термінологію. Товар є економічним благом (продуктом виробничо-економічної діяльності) в матеріально-речовій формі, об'єктом купівлі-продажу, тобто предметом ринкових відносин між продавцями і покупцями [3].

Між виробником і споживачем товару сполучною ланкою $€$ торгівля.

Виробник зацікавлений виробити товар дешевше й продати дорожче; торгівля - посередник - купити дешевше й вигідно продати; споживач - купити дешевше і максимально задовольнити власні потреби.

Вісник Сумського національного аграрного університету Серія «Економіка і менеджмент», випуск 2 (80), 2019 
Виробництво створює предмети, що відповідають потребам; без виробництва немає споживання, однак і без споживання немає виробництва, тому що виробництво було б у такому випадку недоцільно. Без потреби немає виробництва. Але саме споживання відтворює потреби. У цьому складається діалектичний зв'язок між виробництвом і споживанням. Тому у широкому розумінні предметом товарознавства $€$ вивчення споживної вартості всіх продуктів праці: як предметів особистого споживання, так і засобів виробництва [4].

Товаром може бути як матеріальне, так і нематеріальне благо, в тому числі й послуга.

Послуга - це економічне благо, що немає товарної форми, її надають людям, котрим вона потрібна, у формі цілеспрямованої корисної дії чи обслуговування.

Властивість задовольняти ті чи інші потреби (споживчу вартість або корисність) мають не лише продукти праці, але й блага, що безпосередньо дані нам природою повітря, вода, сонячне тепло і світло тощо. Проте вони не створені людською працею і не $є$ товаром. Це означає, що споживча вартість безпосередньо не відбиває ніяких суспільно-економічних відносин, а відображає відносини між людьми та речами, що задовольняють їх потреби [5].

Економічна наука не може не приділяти особливої уваги характеристиці споживної вартості товарів. Товар як споживча вартість (корисність) є, насамперед, предметом, річчю, послугою, яка завдяки своїм властивостям корисна для людей, задовольняючи якусь певну їх потребу (чи групу потреб) - як предмет особистого споживання або як засіб виробництва [3].

Споживна вартість речей, їх корисність для людей тісно пов'язана з прогресом науки і техніки, розвитком продуктивних сил у цілому. Споживна вартість властива не лише товарам, які набувають речової форми - хустка, чоботи тощо, а й послугам - вчителя, лікаря, актора. Особливого значення набуває така споживна вартість, як інформація. Розвиток сфери послуг свідчить про ступінь розвиненості суспільства, про те, як воно піклується про основну його цінність - людину.

3'ясування природи другої властивості товару - вартості - $€$ більш складним. Вартість, на відміну від споживної вартості, не лежить на поверхні явищ. Вартість - це внутрішня властивість товару, зовнішньою формою прояву якої $€$ мінова вартість, уречевлена в товарі суспільно-необхідна праця, що затрачена на виготовлення даного товару [6].

У сфрері торгівлі споживні вартості оцінюються з точки зору цінності і корисності для покупця (споживача), тобто досліджується їх якість, визначаються переваги споживачів щодо того чи іншого виду споживчих товарів. Споживні вартості характеризуються з боку їх кількості (маси, обсягу), асортименту (складу) і якості. Залежно від свого функціонального призначення (характеру споживної вартості) споживчі товари поділяються, зокрема, на харчові продукти і непродовольчі товари.

Отже, споживну вартість товарів слід характеризувати з позицій їх споживчих властивостей як товарів-аналогів, так і товарів-конкурентів, реакцію покупців на нові товари, товарний асортимент, упаковку, рівень сервісу, відповідність товарів регламентним нормам і правилам.

3 економічної точки зору важливим є критерій еластичності попиту на ті чи інші товари. Основними видами товарів щодо еластичності попиту за доходом є: нормальні товари, товари першої необхідності, товари розкоші, інферіорні товари, інші товари. Якщо еластичність попиту за доходом позитива - такі товари відносяться до виду нормальних товарів. Їх можна розділити на товари першої необхідності 3 невисокою, хоча й позитивною або невід'ємною еластичністю за доходом, товари розкоші, величина еластичності попиту на які дуже значна. Якщо еластичність попиту за доходом на товар від'ємна, то такі продукти відносяться до виду інферіорних (малоцінних, неякісних) товарів. Якщо дохід споживача незначний, індивід змушений купувати інферіорний продукт внаслідок неможливості придбати товар кращої якості в умовах низької купівельної здатності. При зростанні доходу покупець намагається позбутися такого продукту на користь нормального товару [3].

Товари за перехресною ціновою еластичністю, як відомо поділяються на:

- взаємозамінні товари, або товари-субститути;

- взаємодоповнювані товари, або товари-комплементи - ці товари взаємодоповнюють один одного у споживанні;

- нейтральні товари.

Взаємозамінні товари надають споживачу одну і ту саму сукупну корисність, задовольняють одну і ту саму його потребу та з точки зору корисності $є$ рівнозначними. Тому для покупця головним критерієм вибору цих товарів стає ціна.

Взаємодоповнювані товари (комплементе) - це товари, які споживаються разом і в певній пропорції. Корисність споживачу приносить лише набір цих товарів із певними пропорціями.

Товари-замінники відображають ситуацію переключення покупців на інший товар, що залежить від того: чи є цей товар у наявності в сфері торгівлі і якою мірою новий товар задовольняє ту ж саму потребу покупців. Чим більше у товару потенційних замінників (субститутів), тим легше покупцям відмовитись від купівлі даного товару. Цей ефект зростає якщо ціна базового товару підвищується, навпаки при зниженні його ціни все більше нових покупців залучається у процес продажу базового товару.

У слаборозвинених економіках при зростанні купівельної спроможності попит домашніх господарств переключається на більш споживні харчові продукти з відносно високою еластичністю - це риба, м'ясо, м'ясопродукти, кондитерські вироби, фрукти, овочі. Попит на них еластичний як за ціною, так й за доходом. При цьому споживання традиційних для домогосподарств харчових продуктів в абсолютному вимірі у загальнонаціональному масштабі, по суті, не зменшується.

Згідно з законом попиту обсяг продаж скорочується при підвищенні ціни одиниці товару. Однак закон попиту має два винятки. Насамперед, це стосується так званих товарів Гіфффена. Товар Гіфффена - це товар, що займає вагоме місце в бюджеті незаможних споживачів, попит на який за інших рівних умов змінюється в тому ж напрямі, що і ціна, оскільки ефект доходу перевищує ефект заміщення.

Ефект Гіффрена має місце стосовно деяких малоцінних товарів, коли при підвищенні їх цін збільшується й обсяг купівлі. Якщо ціна товару підвищується, то для певної категорії споживачів (з низькими доходами, часто на рівні або нижче рівня бідності) зменшення реальних доходів суб'єктивно виявляється таким значним, що вони вимушені розширяти купівлю малоцінних і дешевих товарів, відмовляючись від придбання більш дорогих. 
Отже, незважаючи на підвищення ціни на основний продукт харчування бідних верств населення (як правило, хліб або картоплю) обсяг попиту на нього теж збільшується. Підвищення ціни змушує споживачів з низькими доходами скорочувати споживання інших більш дорогих і якісних товарів [3].

У сучасних умовах ті чи інші товари стають товарами Гіффена в умовах загальної економічної нестабільності, кризи та різких інституційних змін.

Другий виняток із закону попиту стосується товарів престижного споживання. Йдеться про групу споживачів (покупців) з високими доходами. Елемент престижу, орієнтації на підвищення чи, навпаки, «маскування» свого соціального статусу (дійсного або бажаного) відіграє важливу роль у формуванні індивідуальних смаків або переваг, а отже й попиту на певні товари.

Х. Лейбенстайн виділив три типові випадки взаємних впливів у споживчому попиті покупців із середніми та високими доходами (табл. 1).

Ефект приєднання до більшості - це ефект збільшення споживчого попиту, пов'язаний з тим, що покупець, сповідуючи загальноприйняті норми, купує той же самий товар, які купують інші.

Структура соціального попиту взаємних впливів у споживчому попиті покупців

Таблиця 1

\begin{tabular}{|l|l|l|}
\hline 1. & Ефект приєднання до більшості & покупець, прагнучи не відставати від інших, купує те, що купують інші. \\
\hline 2. & Ефект «сноба» (ефрект винятковості) & у покупця домінує прагнення виділитися із загальної групи споживачів. \\
\hline 3. & Ефект Веблена & $\begin{array}{l}\text { має місце престижне чи демонстративне споживання, коли товари використовуються не за } \\
\text { прямим призначенням, а для того, щоб зробити суспільне враження. }\end{array}$ \\
\hline
\end{tabular}

Джерело: сформовано автором

Ефект «сноба» (ефект винятковості) - окремий покупець залежить від вибору інших, але ця залежність обернена. Якщо інші покупці збільшують споживання даного товару, то «Сноб» його скорочує.

Ефект Веблена - це ефект збільшення споживчого попиту, пов'язаний з тим, що товар має вищу (а не нищу) ціну. Ефект Веблена подібний на ефект «сноба». Однак принципова відмінність полягає в тому, що ефект «сноба» залежить від розмірів споживання інших, тоді як ефект Веблена залежить насамперед від ціни. При підвищенні ціни одиниці певного товару покупець може розцінити його купівлю як елемент свого престижу, як статусне споживання, що робить його винятковим в очах інших покупців.

У структурі споживчих товарів виділяються товари економ та преміум-класу.

Економ-клас - це товари невисокої якості. Ціна цих товарів також невисока, в неї закладаються мінімальні бюджети просування, товар відрізняється простотою і проблемним рівнем якості.

Преміум-клас - це товари відомих марок. На перший план тут виходить імідж товару. Покупець переплачує за бренд. У бюджет просування вкладаються досить значні кошти на рекламу. Товари класу «преміум» адресовані групі покупців, яка демонструє слабку чутливість до цінового фактора. У преміум-класі виділяється підклас «делюкс» - ексклюзиввні товари.

В умовах інноваційної економіки все більшого значення набувають наукомісткі (або високотехнологічні) товари в розробку і виробництво яких вкладена висока частка витрат, пов'язаних 3 науково-дослідними і дослідно-конструкторськими роботами. У теорії та на практиці розрізняють ліквідні та неліквідні товари.

Підприємство торгівлі постійно стикається з проблемою неліквідності товарів. Уповільнення реалізації цих товарів гальмує обіг грошових коштів, призводить до затоварення і знижує рівень рентабельності підприємства. На підприємстві торгівлі отримання доходу від продажу товарів $€$ основним напрямом діяльності [3].

Неліквідні товари - це ті товари, які можуть бути конвертовані у грошову форму протягом значного періоду часу.
Неліквідні товари - це залежалі, неходові товари, період реалізації яких розтягується. Протягом цього періоду вони не користуються попитом.

До причин неліквідності певних споживчих товарів до закінчення терміну їх придатності можна віднести:

- моральну або технічну застарілість товару;

- зниження якості товару внаслідок тривалого зберігання або недотримання умов зберігання;

- сезонний характер товару;

- виявлення прихованого дефекту в окремій партії товару;

- настання строку завершення споживання товару та iH.

Щодо такого класу товарів як «мережевий товар» то корисність, яку отримує кожний окремий покупець від такого товару, безпосередньо залежить від кількості користувачів цим (або подібним, сумісним) товаром. До мережевих товарів відносяться, наприклад: телефон, Інтернет, комп'ютери, програмне забезпечення, e-mail, відео- i DVD-програвачі, кредитні картки, телефонні довідники, пошукові інформаційні системи та ін.

За останні роки у зв'язку із розвитком великих торговельних мереж активного поширення набрала така група споживчих товарів як private label - як правило, продовольчі під власними (для мережі) торговельними марками. Нині в Україні усі національні мережі активно розвивають напрям власних торговельних марок (рrivate label). За їх допомогою мережі прагнуть знизити свою залежність від постачальників. Крім цього ця група товарів приносить торгівлі й більший рівень доходу. У найближчій перспективі можлива ситуація, коли товари із власними торговельними марками мереж почнуть витісняти із торгівлі інші споживчі товари. Загрозу не відчуватимуть лише товари із відомими брендами [3].

Важливими чинниками якості товарів сьогодні виступають:

- ефективність технологій їх виробництва,

- висока репутація виробника,

- безпека використання,

- захист від підробок

- високоякісні інгредієнти та ін. 
Єдність ціни і якості товару формує його цінність з позицій сприйняття покупцями. Засобом демонстрації високої якості товару, як правило, вважається його висока ціна. Безумовно, ціна - важливий показник оцінки якості товару. Більшість покупців вважає, що висока ціна є гарантією високих стандартів якості. Однак так буває далеко не завжди. На деформованому ринку споживчих товарів з високою часткою реалізації контрафактних товарів покупець часто-густо не може кваліфіковано судити про якість пропонованого йому товару.

у світі все більше утверджується думка про необхідність «глобально гармонізованих» стандартів та їх взаємного визнання. Оскільки технологія виготовлення продукції істотно змінилися, з'явилися нові параметри, показники безпеки, то і державний стандарт став включати жорсткіші вимоги до товарів. I ДСТУ (Державний стандарт України), і ГОСТ (Державний стандарт) потрібні для того, щоб регулювати обов'язкові вимоги до якості продукції (сухість, вологість, кількість білків-жирів-вуглеводів і т.д.).

Вирішальне значення мають технічні регламенти споживчих товарів. Технічні регламенти розробляються, приймаються та застосовуються на основі принципів, установлених Угодою СОТ про технічні бар'єри у торгівлі, що є додатком до
Марракеської угоди про заснування СОТ 1994 р. Технічні регламенти в Україні розробляються на основі: міжнародних стандартів, якщо вони вже прийняті або перебувають на завершальній стадії розроблення, чи їх відповідних частин; регіональних стандартів, національних стандартів України чи інших держав, актів законодавства ЄС. Під технічним регламентом розуміється нормативно-правовий акт, в якому визначено характеристики продукції або пов'язані з ними процеси та методи виробництва, включаючи відповідні процедурні положення, додержання яких є обов'язковим. Він може також включати або виключно стосуватися вимог до термінології, позначень, пакування, маркування чи етикетування в тій мірі, в якій вони застосовуються до продукції, процесу або методу виробництва [3].

Висновок. Таким чином, краще розуміння «товару» як економічної категорії дозволяє вийти на новий рівень наукового дослідження сутності та перспектив розвитку внутрішньої торгівлі. Важливим та необхідним, крім того, $є$ аналіз споживної вартості та корисності споживчих товарів із точки зору їх розуміння як технічної категорії. Також, необхідність розробки стандартів на товари та їх взаємного визнання, гармонізувати їх 3 європейськими, використовувати виробникам технічні регламенти для споживчих товарів.

\section{Список літератури:}

1. Товарознавство непродовольчих товарів / [Л. Г. Войнаш, І. О. Дудла, Д. І. Козьмич та ін.]. Підручник. Част. 1. - Київ: НМЦ «Укоопосвіта», 2004. - 436 с.

2. Титарєнко Л. Д. Теоретичні основи товарознавства: навч. пос. / Л. Д. Титарєнко. - К: Центр Навчальної літератури, 2003. - 227 c.

3. Внутрішня торгівля України: монографія / А.А. Мазаракі, В.Д. Лагутін, А.Г. Герасименко [та ін.]; за заг. ред. д-ра екон. наук, проф. А.А. Мазаракі. - Київ : Київ. нац. торг.-екон. ун-т, 2016. - 864 с.

4. Теоретичні основи товарознавства: навч. посіб / Ю. Т. Жук, В. А. Жук, Н. К. Кисляк та ін. - К.: НКЦ «Укоопосвіта», 2000. -250 c.

5. Білецька Л. В. Економічна теорія. Навч. пос. / Л. В. Білецька, О. В. Білецький, В. І. Савич. - Київ: Центр учбової літератури, 2009. - 688 c.

6. Основи економічної теорії: політекономічний аспект [Текст]: навчальний посібник для студ. вищ. навч. закл. / А. А. Григорук, М. С. Палюх, Л. М. Литвин, Т. Д. Літвінова. - 2-ге вид., переробл. і допов. - Тернопіль : ТДПУ, 2002. - 304 с.

Danylo S.I., PhD, Uzhgorod Trade and Economic Institute of KNTEU (Uzhgorod, Ukraine)

Contemporary understanding of goods as an object of trade.

The article analyzes the approaches to contemporary understanding of "goods" as an economic category that contributes to achievement of a new level of scientific research of the nature and perspectives of trade development. The directions by which it is reasonable to evaluate the efficiency of demand elasticity for certain goods are outlined. The structure of social demand of mutual impacts in consumer demand is analyzed.

Keywords: goods, trade, consumer goods, demand, consumers.

Дата надходження до редакції: 26.01.2019 р. 